\title{
人間工学専門家資格認定制度に関する調査報告
}

\author{
○川村浩子，高見正人，鈴木一重（（社）人間生活工学研究センター）， \\ 人間工学専門家資格認定制度専門委員会（委員長；菊池安行（千葉大））
}

\section{Report on a certification program for professional ergonomists}

Hiroko Kawamura, Masato Takami, Kazushige Suzuki

(Research Institute of Human Engineering for Quality Life),

Ad hoc commitee on a certification program for professional ergonomists

(Chair ; Yasuyuki Kikuchi(Chiba Univ. ))

\section{1 はじめに}

人間工学専門家資格認定制度は、企業 に従事する人々の労働環境の改善、安全 及び健康を確保したり、製品（環境を含 む）の操作性等を向上するために、人間 工学の専門家を育成し、その専門性を保 証する制度である。欧米では、既に人間 工学専門家資格認定制度が設立・実施さ れており、併せて約700名が専門家として 認定されている。また、IEAにおいても、 専門家の資格認定基準を国際的に整合さ せる動きにある。さらに、PL法の施行及 びISOやCENなどの人間工学関連のガ价う 价規格の動きが活発化しており、ます ます人間工学が国際的に活躍する情勢で ある。

日本では、日本人間工学会によって数 年前より制度創設に向けた検討が行われ ており、当センターもこの重要性に着目し、 昨年4月に日本人間工学会と共同で、人間 工学専門家資格認定制度について検討す るために専門委員会を設置した。

\section{2 委員会の検討内容}

検討内容：1）人間工学の定義 2）人 間工学の役割 2) 専門家が身に付けるべ き知識、技術、経験（資格要件）。 調査方法 :

1）国内ア次ート・ヒアリ放”調査

(1)企業における人間工学の活用・評価

(2)大学の教育の現状と将来の課題

2) 海外文献及び実地調査

(1)欧米の資格制度設立背景と現状

(2)大学の人間工学教育の現状

(3)企業における人間工学の活用と評価

\section{3 検討と調查結果}

\section{1 討議結果}

現在、人間と技術の乘離がクローズア ップされており、この状況を解決する手 段として人間工学が注目されている。労 働環境の安全性確保や製品の操作性の向 上に、人間工学が重要な役割を果たすと の認識が得られた。

ところで、人間工学が活用されるため には、基礎技術の発展及び人間と環境に 関するデータの整備はもちろんのこと、こ れを駆使する人材が必要である。人材育 成は、大学の学生及び企業で働く社会人 の両者が対象となる。その解決の方策と して、学生には、大学の扐沛么の充実と 学部・学科の増設、企業における実務訓 練を、社会人には生涯教育などのシ行ムの 整備が今後の課題である。また社会人の 技量の客観的尺度として、さらにはPL訴 訟や国際規格などの国際化の対応として も、専門家の資格認定制度が重要な位置 を占めるとの討議がなされた。

3.2 海外調査結果

3.2 .1 資格認定制度

【制度設立の経緯と目的】

ア归カでは、1960年代より人間工学会が 資格制度創設の検討を始めており、1990 年6月にBCPE (Board of Certification in Professional Ergonomics、人間工学専門家 資格認定団体)が設立された。

制度のねらいは、1）能力の不十分な技 術者から社会を守る 2) 有能な専門家の 高潔を守る 3）専門家の雇用機会の増強

4）大学教育 ${ }^{\circ}$ 㕫 么への要求の明確化

5）人間工学への認識・地位向上 
PL訴訟等の場合、裁判官や弁護士に客観 的判断材料を提供することである。

一方、欧州では、1992年に欧州統一組

織として、専門家を認定するCREE (Centre for Registration in European Ergonomists、欧 州人間工学専門家登録セン多)が設立された。

制度のねらいは、1)教育及び訓練プログ うムに関するEC加盟国間の相互認証の促進

2）EC内の専門水準の構成要素の体系化 と評価のための枠組み提供 3) EC内で資格取得者の流動性の促進

人間工学の専門的イメージの向上。

【専門家資格要件】

\section{アメリカ (BCPE) の資格要件}

1）人間工学（関連分野の）修士課程修了

2）4年間の実務経験 3）人間工学関係の プロジェクトの提出 4) 筆記試験

\section{欧州（CREE）の資格要件}

1）人間工学教育 1 年間を含む 3 年間大学教 育 2）最低1年間の訓練 3）最低2年間 の経験

ねらいからは、専門家の能力保証を前 提に、ア刚力ではPL訴訟、欧州ではEU統合 による移動性が掲げられ、それぞれの背 景に合わせて本制度が設立されたことが 伺える。現在、両団体は、双方の資格要 件について、その基準を相互に認め合っ ている。日本が新たに設立する場合にも、 日本の事情に合ったねらいの設定が必要 であると共に、資格要件が国際的整合性 に影響されることが予想される。

【制度運用状況】

欧米ともに、本制度に対する認識はま だ高くはないが、関係者は普及するよう に積極的に活動している。資格取得者 は、教育関係者及び研究者より、コン州外 等の人間工学を応用する人々が多い傾向 にある。特に欧州では、国を越えCREEが 行っているため、今後、意義が一層期待 されている。

\section{2 .2 大学教育}

ア归では、制度設立が、教育归ュラムの 改良をもたらした。人間工学会の調査認 定委員会が、各大学のカリキュラムを審 査し、現在10校を認定している。講義や 実習・実験内容、企業実習、論文の有無 などによって判断されており、各大学は この基準を下に、扐执編成の努力を続 けている。

欧州でも同様に、HETPEP (Harmonizing
European Training Programs for Ergonomics Profession、欧州統一訓練プログう幺）レポート

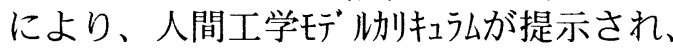
加キュうムの標準化が行われた。現在、各大 学で見直しを検討している。

\section{2 .3 産業}

欧米ともに、日本に比べ製品開発より、 労働環境の改善に人間工学が取り入れら れていた。また専門家としては、知識・ 訓練と共に、経験が非常に重視されてい た。ア帅カでのPL訴訟における専門家の役 割は、まだ明確になっていない。

欧州では、人間工学の位置づけが各国 で若干異なった。しかしヨーロッ゚デ 收ティ゚ の影響が大きい。PL訴訟への意識は低い。 3.3 国内調査結果

\section{3 .1 大学教育}

84大学を対象に郵送による調査を行った。 今後の課題：1）人間工学の教育従事者 の人材の充実 2) 教育加扫公整備（特 に実験・実習の充実）3）人間工学テ祈 の作成 4）企業実習・現場訓練の補強 5）生涯教育のシ人㣗構築

\section{3 .2 企業の現状}

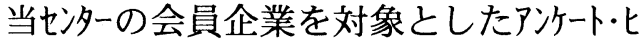
アリングでは、人間工学の今後の発展・貢献 が期待されており、大学扐㧈改善や 強度研究などを通して産・学の協力の促 進を課題として挙げている。

\section{4 まとめ}

国内外の調査結果より、日本としては、 今後専門家資格認定制度の創設を目指し ていくべきとの結論が出された。

わが国においては、以下のような問題 点を今後検討する必要がある。

\section{1）資格制度設立の重要性と目的の明確} 化2）生涯教育を含めた教育沜ュュラの整 備

最後に、人間工学専門家資格認定制度 により、我々生活者及び企業が真に利益 を享受できることが重要である。

(なお、この調查研究は日本自転車振興 会の補助研究に協力して行われたものであ る。)

\section{参考文献}

1)人間工学専門家資格認定制度調査事業報 告書、（社）人間生活工学研究センタ -,1995 